\title{
КОРЕКЦІЙНІ ПРИЙОМИ РЕАЛІЗАЦІЇ ІНДИВІДУАЛЬНОГО ПІДХОДУ В УМОВАХ СПЕЦІАЛЬНОГО НАВЧАННЯ УЧНІВ 3 КОМПЛЕКСНИМИ ПОРУШЕННЯМИ
}

Ірина Родименко, Оксана Михайленко, К30 «Багатопрофільний навчально- реабілітаційний ресурснометодичний центр корекційної роботи та інклюзивного навчання» ДОР»

Розглянуто проблеми організації індивідуального навчання дітей із складними порушеннями психофізичного розвитку в умовах сучасної України. Наведено прийоми реалізації індивідуального підходу в навчанні учнів із комплексними порушеннями в умовах спеціального навчання.

Ключові слова: комплексні порушення, учні з порушеннями слуху, корекційне навчання, індивідуальний підхід, альтернативні методи комунікації.

Ирина Родименко, Оксана Михайленко, К30 «Многопрофильный учебно-реабилитационный ресурсно-методическый центр коррекционной работы и инклюзивного обучения ДОР»

Коррекционные приемы реализации индивидуального подхода в условиях специального обучения у детей с комплексными нарушениями психофизиологического развития

Рассмотрено проблемы организации индивидуального обучения детей с множественными нарушениями психосризиологического развития в Украине. Описано приемы реализации индивидуального подхода в условиях инклюзивных учебно-реабилитационных центров для детей с особыми образовательными потребностями.

Iryna Rodymenko, Oksana Mikhailenko, MEI Multidisciplinary educational-rehabilitation resourcemethodical center of correctional work»

Corrective techniques of implementation of the individual approach in the conditions of special education in children with complex psychophysiological development disorders

The problems of organizing individual education of children with multiple disorders of psycho-physiological development in Ukraine are considered. We describe the techniques for implementing an individual approach in an inclusive education and rehabilitation centers for children with special educational needs.

Keywords: complex infringements, students with hearing impairments, correctional training, individual approach, alternative methods of communication. 
Актуальність статті. Складні економічні умови, погіршення екологічної ситуації, техногенні перевантаження, неблагополучні умови праці жінок, недосконалість наявної системи медичного і соціального забезпечення, високий рівень захворюваності батьків, погіршення якості продуктів харчування, зростання стресових ситуацій у повсякденному житті спричиняють збільшення кількості дітей iз різними видами захворювань. Так, за 2003-2012 рр. чисельність дитячого населення знизилася на 19,02 \%. Водночас, загальна чисельність дітей-інвалідів щорічно збільшується на 0,5 \%. Чисельність дітей-інвалідів станом на початок року сягнула показника 167059 осіб або 2,0 \% від усього дитячого населення країни [16].

За даними статистики, в Україні налічується понад півмільйона дітей із порушеннямислуху, понад 7,5 тис. дітей страждають розладами аутичного спектра. Щорічно народжується більше як 400 дітей із синдромом Дауна, нині в країні зареєстровано понад 15 тис. осіб із цим захворюванням. Понад 20 тис. дітей з дитячим церебральним паралічем (ДЦП). Синдром дефіциту уваги і гіперактивності (СДУГ) спостерігається у 7 \% українських дітей. При цьому офіційна статистика не відображає реальної картини і ці цифри на багато вищі [5]. На 22,4 \% збільшилася мережа навчальних закладів для дітей зі складними порушеннями розвитку (навчально-реабілітаційних центрів) та відповідно учнів у них: 2015/2016 н. р. - 58 закладів (6,4 тис. учнів), 2016/2017 н. р. - 71 (7,9 тис. учнів) [16]. Навчання, виховання і реабілітація дітей зі складними порушеннями є маловивченою і складною проблемою спеціальної педагогіки. В учнів із комплексними порушеннями розвитку часто виникають труднощі в оволодінні навчальним матеріалом у терміни передбачені програмами, маючи при цьому складнощі в процесі соціальної інтеграції [2].

Дослідники цього питання поділяють, залежно від структури порушення, дітей із поєднаними порушеннями на три основні групи:

1. Діти, з двома вираженими психофізичними порушеннями.

2. Діти, які мають одне виражене психофізичне порушення і супутнє йому інше порушення, виражене в слабкому ступені.

3. Діти, які мають три або більше порушень виражених в різному ступені (множинні дефекти. До множинних дефектів, зокрема, можна віднести і поєднання в однієї дитини кількох невеликих порушень, які мають негативний кумулятивний ефект, наприклад, при поєднанні невеликих порушень моторики, зору і слуху в дитини може мати місце виражене недорозвинення мови [6].

Вважають, що діти зі складними порушеннями розвитку - це рідкісна, статистично малозначима категорія. Тим часом, згідно з даними досліджень і спостереженнями досвідчених дефектологів-практиків, такі діти становлять у середньому до 40 \% контингенту спеціальних освітніх установ. Практична потреба у вивченні цих дітей, визначенні їх освітніх потреб та у розробленні системи їх реабілітації виключно велика.

Аналіз останніх досліджень. Вагомий внесок у розробку шляхів і методів реабілітації дітей з комплексними порушеннями зробили В. Бондар, Л. Вавіна, Н. Ф. Засенко, В. Засенко, Т. Сак, С. Соботович, В. Синьов, В. Назарова, 
О. Хохліна, Т. Сжова, утім питання організації індивідуального підходу в навчанні дітей зі складними порушеннями психофізичного розвитку в умовах багатопрофільного навчально-реабілітаційного центру залишається недостатньо вивченим.

Метою статті є висвітлення окремих корекційних прийомів роботи з учнями, що мають комплексні психофізичні порушення як на уроках, індивідуальних заняттях, так і в позаурочний час.

Особливим завданням спеціальних освітніх закладів є корекція розвитку дітей. Його вирішення є не менш важливим і для інших типів закладів, у яких можуть навчатися діти з певними порушеннями розвитку. Компонентами спеціальної освіти є процеси навчання, виховання та корекція. При цьому корекція розглядається як основа навчально-виховної роботи в спеціальній школі: без цілеспрямованого подолання чи послаблення недоліків знижується ефективність навчання й виховання дітей: ускладнюється процес оволодіння необхідними для них знаннями, вміннями, навичками, становлення в них поведінки, особистості загалом. Водночас зауважимо, що виділити складові частини спеціальної освіти (навчання, виховання, корекція) можливо лише абстрагуванням функцій кожної 3 них для їх осмислення, організації, цілеспрямованої роботи. Якщо корекцію та навчання (і виховання) брати як відносно самостійні компоненти педагогічної системи, то відмінність між ними полягає в меті, особливостях педагогічного процесу, показниках ефективності.

Так, мета навчання - дати учням знання, уміння та навички, мета корекції виправляти порушення психічної і фізичної сфер розвитку, розвивати дитину загалом. Досягнення мети корекційного впливу забезпечують усі складові педагогічного процесу - організація, зміст, методика. Проте особливості корекційнорозвивального впливу визначаються не так закономірностями засвоєння навчального матеріалу, як його метою, визначеною відповідно до предмета корекції, його сутності, психологічних закономірностей впливу на нього. Саме від предмета корекції, тобто від того, що необхідно виправляти та розвивати в дитини, залежить постановка мети, пошук спеціальних шляхів організації педагогічного процесу, добір відповідних методичних засобів та змісту навчання, визначення показників його результативності [17].

Не можна залишати поза увагою суперечності між загальними для всього класу педагогічними вимогами (єдиний темп навчання, зміст програмового матеріалу) і різним рівнем розвитку пізнавальних можливостей учнів. За цих умов фронтальна робота з учнями може бути малоефективною. У будь-якому класі є учні, яким важко засвоїти передбачені програмою предмета знання [2].

Отже, диференційоване навчання за групами залежно від рівня навчальних можливостей є однією з важливих умов реалізації принципу індивідуального підходу. Вивченням цього питання займалися I. Сременко, Л. Вавіна, Г. Мерсіянова, Н. Ф. Засенко та ін.

Важливого значення на початковому етапі знайомства з учнем та батьками та для вибору стратегії корекційного навчання та реабілітації учня 3 особливими освітніми потребами набуває вивчення анамнезу, діагнозу дитини, анкетні дані.

«ОСОБЛИВА ДИТИНА: навчання і виховання», № 3, 2019 


\section{Корекційні прийоми реалізаціі індивідуального підходу}

Відповідно до методик навчання та виховання дітей із порушеннями слуху та інтелектуальними порушеннями, за умови, що особливості пізнавальних процесів та пізнавальної діяльності відповідають рівню затримки психічного розвитку має здійснюватися у спеціальних закладах, при цьому індивідуальне навчання, так само, як і його колективні форми, мають бути корекційно спрямованими. Для цього застосовуються такі корекційні прийоми:

- адаптація змісту освіти до пізнавальних можливостей учнів, що виявляється в зменшенні обсягу матеріалу, його спрощенні за характером і структурою;

- наочність навчання: використання різних видів наочності, їі відповідність рівню розвитку сприймання й мислення дитини, поступове ускладнення (від реальних предметів та об'єктів до символічної наочності), задієння якомога більшої кількості аналізаторів (слух, зір, дотик, нюхові аналізатори, вібраційне сприймання), поєднання наочних методів із словесними, практичними;

- уповільненість процесу навчання з урахуванням інертності нервових процесів дітей;

- повторюваність у навчанні та вихованні з метою ліквідації фрагментарності сприймання, недосконалості запам'ятовування. Повторення має бути систематичним, різноваріативним, з різним ступенем залучення дитини;

- залучення учня в діяльність, спрямовану на подолання труднощів і перешкод (принцип вправляємості) - усі теоретичні відомості, правила мають бути засвоєні через практичну діяльність різного ступеня труднощів і новизни; без відпрацювання вмінь у практиці подолати наявний в учнів розрив між теорією й практикою неможливо;

- спеціальна організація праці - у процесі роботи треба вчити учня планувати свою діяльність, міркувати про послідовність та способи виконання, описувати результати й порівнювати ї із зразком;

- використання гри у навчально-корекційній роботі - 3 метою підвищення інтересу дитини до навчальної діяльності, подолання їі пасивності доцільно використовувати як дидактичну, так і сюжетно-рольову гру;

- дотримання охоронно-педагогічного режиму з урахуванням конкретного клінічного діагнозу.

Розвитку та ефективності роботи з ними в умовах корекційної та інклюзивної освіти позитивні емоції педагога слугують засобом стимулювання дитини до навчальної діяльності й спілкування, формують їі віру в свої можливості [6].

Щоб виправлення мовленнєвих порушень відбувалося ефективніше, у дітей потрібно формувати потребу в спілкуванні. Дослідники зазначають, що дітям із мовленнєвими порушеннями та порушеннями слуху, так само як і ї ровесникам із нормальним мовленням, украй важливо задовольняти, окрім потреби у спілкуванні, чимало інших потреб, які можна розподілити на три великі групи:

- біогенні (потреби в активності, орієнтуванні);

- nсихофізіологічні (потреба в емоційному насиченні та розрядці, потреба в діяльності); 


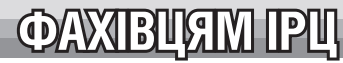

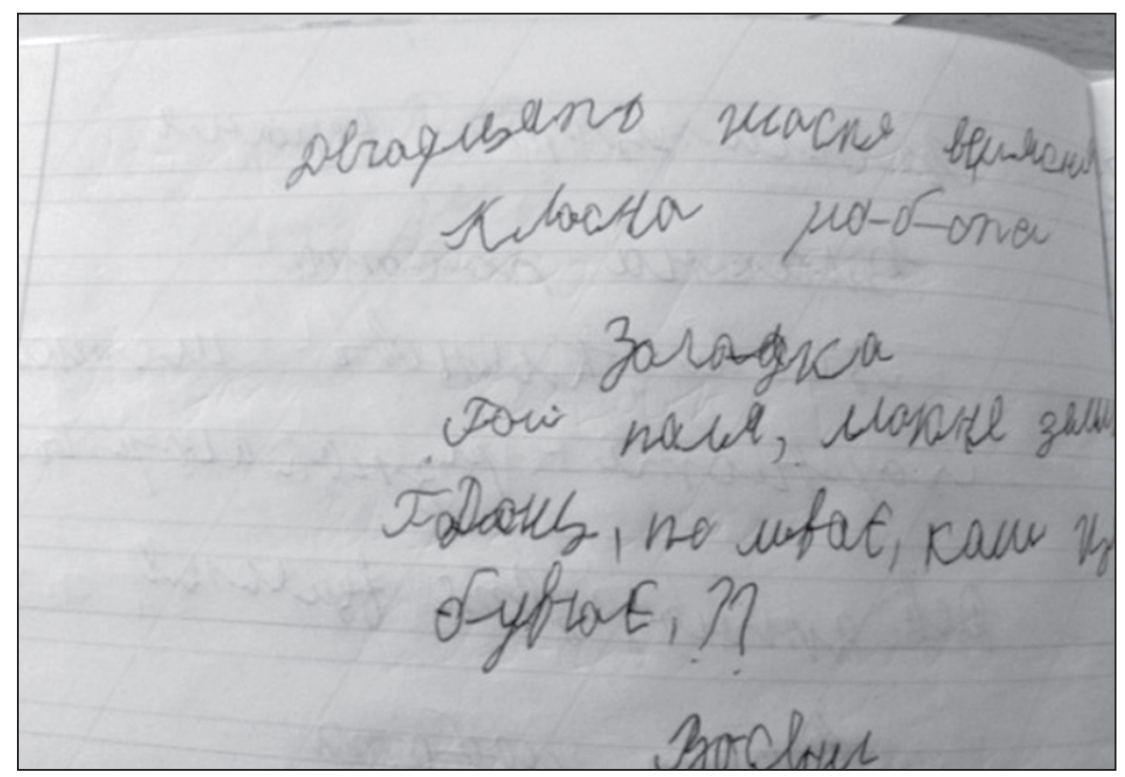

Зразок роботи учня до початку роботи над зоровими диктантами

- соціальні (потреба в реалізації та ствердженні свого «Я», потреба у афілітації (бути у групі таких, як і він (вона) сам (-а), потреба у спілкуванні).

Зупинимося детальніше на окремих корекційних прийомах та методах, які ми використовуємо під час уроку для реалізації індивідуального підходу.

Приклад 1. Учень 2 класу Микита С. Висновок ІРЦ: Порушення слуху у формі двосторонньої сенсоневральної туговухості III ступеня. Дефіцитарний психічний розвиток у дитини з порушеннями слуху. Особливості пізнавальних процесів та діяльності відповідають рівню затримки психічного розвитку. Працездатність нестійка. Емоції незрілі. Обмежений рівень мовленнєвого розвитку. 3 початком навчання в БНРЦ також було діагностовано дисграфію та дислексію. Микита має значні труднощі в оволодінні письмом та читанням. Протягом навчання на уроках і додаткових заняттях у позаурочний час Микиті пропонувалися додаткові завдання для розвитку дрібної моторики (легоконструювання, пальчикові ігри тощо).

Для індивідуальної роботи ми почали використовувати метод «зорових диктантів» за методикою професора I. Федоренка, де кожне наступне речення на одну-дві букви більші від попереднього.

Часу на цей вид роботи витрачається мало, а результат помітний, звичайно за умови, що диктанти проводяться щоденно. До них добираю різні граматичні завдання. Отже, читацькі навички Микити значно поліпшилися, є певні успіхи у написанні літер. Тепер учень пише тільки у робочому рядку. Зразки учнівських робіт до та після проведеної роботи наведено в малюнках.

Приклад 2. Учень 3 класу Гліб К. Медичний діагноз: двостороння сенсоневральна глухота в дитини з кохлеарним імплантом справа. Органічний розлад особистості та поведінки. Складний міопічний астигматизм обох очей. 

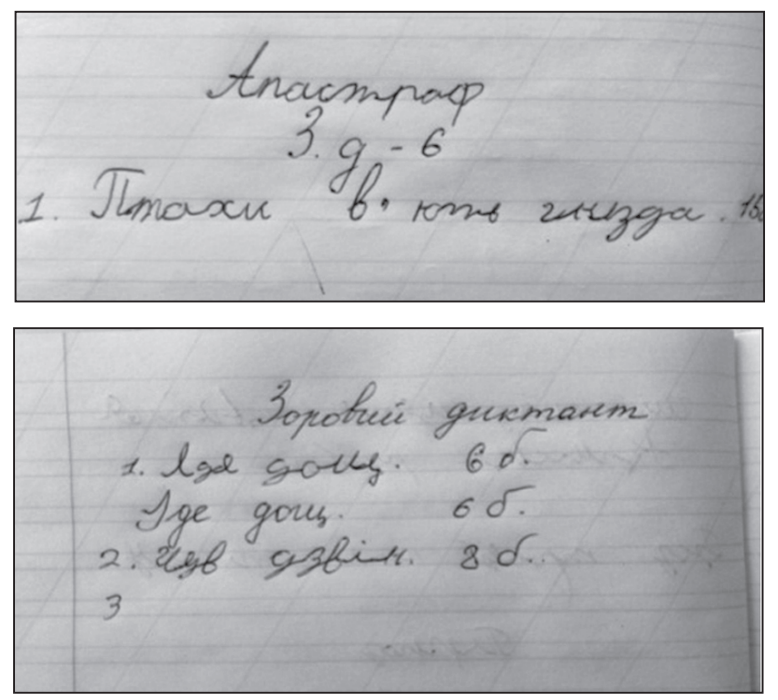

Результат роботи після надання зорових диктантів

Висновок ІРЦ: Дефіцитарний психічний розвиток у дитини з порушенням слуху. Особливості пізнавальних процесів та пізнавальної діяльності відповідають легкій розумовій відсталості. Працездатність знижена. Проявляє бурхливі протестні реакції на труднощі на невдачі. Поведінка розгальмована, важко регулюється мовленням. Системне недорозвинення мовлення тяжкого ступеню.

Хлопчик був агресивним, мав прояви аутоагресії, відмовлявся працювати без мами, негативно реагував на незрозумілі для нього завдання.

Для створення комфортного корекційного на навчально-виховного середовища та поліпшення роботи на уроці спеціально для Гліба ми:

- адаптували програмовий матеріал до пізнавальних можливостей учня (що виявляється в зменшенні обсягу навчального матеріалу, його спрощенні за характером і структурою);

- увели додаткову наочність і альтернативні методи навчання.

У результаті аналізу наукових джерел та інформації інтернетних-ресурсів було встановлено наявність різних систем АК, найпоширенішими з яких є Picture Communication Symbols, Makaton, Signalong, Bliss [1]. Спільним для всіх систем є поєднання альтернативного засобу комунікації зі словом, яке доцільно пропонувати дитині в усній і письмовій формах. Залежно від збережених можливостей та рівня розвитку, дитина може обрати ту складову системи, яка краще їй підходить. Так, наприклад, звернену мову дитині може бути легше сприймати в усній формі, а власні висловлювання виражати жестами чи піктограмами.

За видом невербальних засобів системи альтернативної комунікації можна класифікувати так: системи з використанням картинок; з використанням піктограм; з використанням жестів; $з$ використанням символів; з поєднанням піктограм або картинок з жестами. Спільною ознакою різних систем АК є наявність основного (ключового) та додаткового (розширеного) словників, відбір слів до 
яких здійснено з урахуванням принципу частотності [7]. Ми не мали на меті вводити піктограми.

Робота починалася з розвитку в дитини здатності до розуміння природних жестів (згода і заперечення - кивок і похитування головою, вказівний жест, жест-вітання, прощання тощо). Наступний крок передбачає розвиток у дитини здатності до розуміння наслідувальних жестів («істи», «мити руки», «одягатися» тощо). Після того, як учень засвоїв декілька жестів переходили до формування в нього вміння впізнавати об'єкти з найближчого оточення спочатку на фотографіях, потім - на картинках. Коли дитина звикне до графічних об'єктів та зрозуміє іх призначення, iї ознайомлюють з графічним зображенням уже знайомих жестів. Нові слова вводять тоді, коли попередні засвоєні хоча б частково. Усі невербальні висловлювання дитини дорослий має озвучувати («ти хочеш пити», «ти просиш яблуко» тощо). Також потрібно пам'ятати про необхідність регулярного моніторингу розвитку дитини.

Використовуючи знання про картки PECS ми розробили Глібові індивідуальні картки 3 його фото, з частини 3 них ми створили альбоми 3 короткими історіями із життя хлопчика. Починаючи із слова, ми поступово ускладнювали матеріал.

У роботі ми намагалися задіяти якомога більшу кількість аналізаторів. Гліб кохлеарно проімплантований, що дає йому можливість чути більше звуків навколишнього середовища. Важливим видом роботи з таким учнем є розвиток слухового сприймання, співання пісень, слухання немовленнєвих звучань. Такі види роботи дуже подобаються учневі. Він з радістю слухає та співає, що дає нам можливість також відволікти, переключити його увагу у випадку агреciï, протестного сприймання незрозумілого для хлопчика завдання.

Ми використовували такі прийоми і методи роботи з учнем:

- поєднання наочних методів із словесними і практичними;

- робота в уповільненому темпі;

- повторення пройденого матеріалу в навчанні та вихованні з метою ліквідації фрагментарності сприймання, недосконалості запам'ятовування. Повторення має бути систематичним, різноваріативним, з різним ступенем залучення дитини;
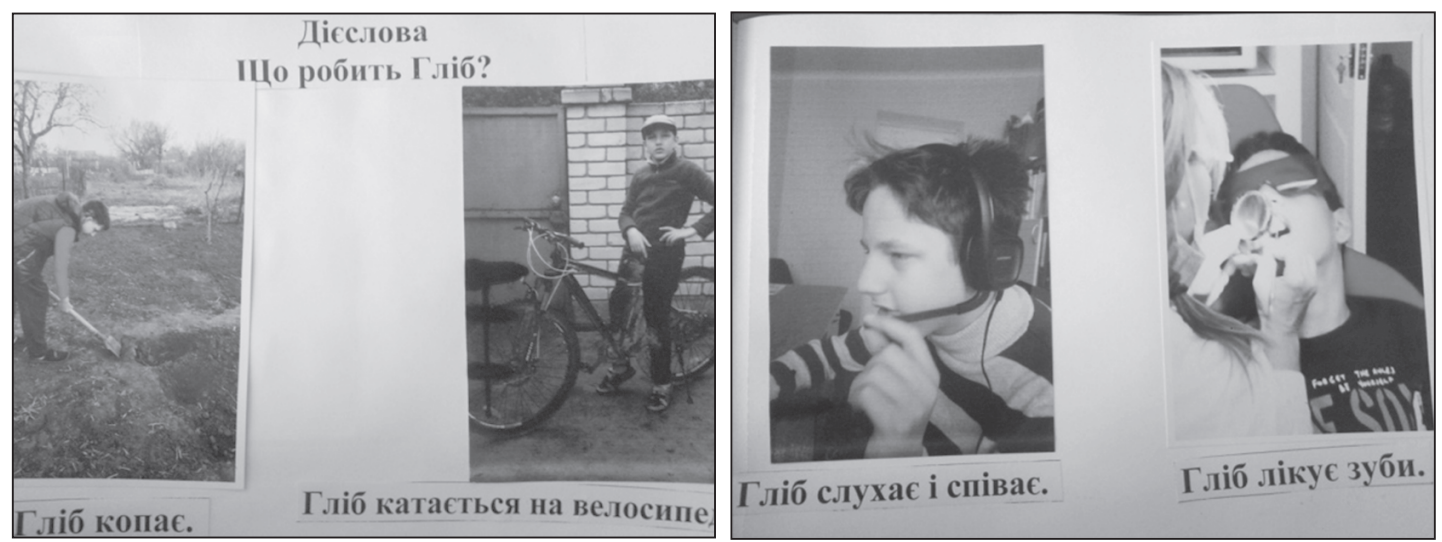

Зразок альбому для розвитку мовлення учня 
- залучення дитини в діяльність, спрямовану на подолання труднощів та перешкод - усі теоретичні відомості, правила мають бути засвоєні через практичну діяльність різного ступеня труднощів та новизни;

- навчання дитини у процесі роботи планувати свою діяльність, міркувати про послідовність та способи виконання на рівні наданого шаблон;

- використання різноманітних ігр у навчально-корекційній роботі - з метою підвищення інтересу дитини до навчальної діяльності, подолання як пасивності, так і агресіі;

- дотримання охоронно-педагогічного режиму з урахуванням конкретного клінічного діагнозу;

- позитивне сприймання всіх правильно виконаних завдань, заохочення учня до навчальної діяльності й спілкування, формування віри в свої можливості.

Також у роботі з Глібом ми активно використовували телефон та комп'ютер. Учневі легше друкувати знайомі слова, ніж писати. Ми навчали відповідати на запитання, використовуючи клавіатуру телефону.

Отже, на кінець року отримали хороші результати порівняно з попередніми. Програмовий матеріал 3 класу засвоїв на середньому рівні. Математику засвоїв на достатньому рівні. Цей предмет учневі дуже подобається. У рамках програмового матеріалу рахує швидко. Гліб розуміє сутність прийомів додавання та віднімання трицифрових чисел, виконує дії з ними, називає усно, дактильно. Поліпшилося розуміння сутності дій множення та ділення. Застосовує алгоритм додавання і віднімання в стовпчик. Розв'язує рівняння. Здійснює перевірку. Геометричні фігури креслить. Задачі розв'язує з допомогою вчителя (за коротким записом). Таблиці множення та ділення засвоїв. Предмети мовленнєвого циклу даються дуже важко, але з'явилося розуміння деяких завдань, став краще працювати за шаблоном. Знає що таке іменник, розрізняє за запитанням хто? що? Складає з допомогою речення. Підкреслює головні та другорядні члени речення. Почали писати диктанти на слухо-зоровій основі. Читання поскладове. Повільне без дотримання пауз та інтонування. Прочитане не розуміє. Пасивний словниковий запас обмежений. Але поступово формується. Добре розуміє дактиль.

Усні завдання з предметів старається виконувати добре, у разі помилки сердиться. На запитання не відповідає. Письмові завдання виконує вибірково. Незрозумілі завдання викликають у Гліба роздратування, спалахи агресії, але значно менші порівняно з початком навчального року. Поведінка поліпшилася. Гліб став спокійніше, завдяки чому ми мали можливість опановувати більшу кількість навчального матеріалу, ніж раніше. Покращилася ізольована вимова звуків, але самостійне мовлення не розвивається. Потребує заохочення до промовляння слів, але пасивний словник формується. Може друкувати окремі слова на клавіатурі, працювати із зоровими словниками.

У побутовому плані став організованішим. Самостійно готується до уроку, почав прибирати шкільне приладдя в портфель у кінці заняття. На уроках більше не кричить, обличчя руками не закриває, зникли прояви аутоагресії. Спостерігається позитивна динаміка - почав вітатися і прощатися, збирати портфель, 
намагається щось розповідати про події з життя. Проявляє велику зацікавленість до дітей.

Приклад 3. Владислав А. Діагноз: сенсоневральна туговухість I-II ступенів. Афазія. Порушення інтелекту.

Учень навчається в класі, але потребує складання не лише індивідуальної програми розвитку, а й окремого індивідуального календарного плану, у якому враховано особливості, корекційні та освітні потреби учня, відповідно до його діагнозу. Під час складання плану корекційно-педагогічної роботи вчитель уточнює у лікаря форму афазії, збереження або порушення функцій тім'яних відділів, які визначаються дослідженням конструктивно-просторового праксису, рахункових операцій тощо.

Згідно з діагнозом учня, індивідуальною програмою розвитку передбачено певну кількість годин на роботу з логопедом з формування внутрішнього мовлення учня, а також сурдопедагога з розвитку слухо-зоро-вібраційного сприймання та формування вимови. Учень також потребує введення альтернативних методів комунікації. Хлопчик добре спілкується жестами.

Для подолання порушення мовленнєвої пам'яті необхідно або відновлення системи зорових уявлень про предмет, його істотних, відмінних ознак, або поступове розширення обсягу слухомовленнєвої пам'яті, порушеної суто за акустичними ознаками сприймання словосполучення, а також подолання експресивного аграматизму, близького за своїми особливостями до експресивного аграматизмів при афазії. При будь-якій формі афазії корекційної роботи потребують усі сторони мовлення: експресивним, розумінням мовлення, письмом і читанням.

Для подолання мовленнєвих розладів у дітей з афазією вчитель в індивідуальній роботі спирається на збережений у них механізми кодування мовленнєвого висловлювання, тобто на опис ознак предмета, введення слова в різні контексти, на складання зовнішніх опор, дає змогу учневі утримувати різний обсяг мовленнєвого навантаження.

Особливу роль у процесі відновлення мовних функцій відіграє письмова мова. Завдяки чому ми починаємо роботу з формування внутрішнього мовлення, на основі якого згодом учень буде будувати своє висловлювання. Збереження письмової мови поступово готує на внутрішньомовному рівні синтагматичний розподіл фрази на відрізки (складається з двох-трьох слів), пов'язані один з одним.

Відновлення слухомовленнєвої пам'яті. Поліпшення слухомовленнєвої пам'яті відбувається з опорою на зорове сприймання. Перед учнем розкладають серії предметних картинок, назви яких попередньо кілька разів читають і пишуть. Так, дитина знає, що вона має почути. Так формуються передумови акустичного передбачення.

Учитель не фіксує увагу учня на необхідності показу предмета у строго визначеній послідовності, не розкладає перед дитиною предметні картинки, а дає їх стопкою для того, щоб прослухавши названі предмети, знайшов ці предмети на картинках і відклав убік. Згодом учитель пропонує повторити серію слів, опрацьованих на попередніх заняттях, а не вдаючись до допомоги картинок. Для запам'ятовування ми подаємо слова, що позначають предмети, потім 
дії і ознаки предметів і, нарешті, числа, об'єднані в номери телефонів. Паралельно з цим проводять слухові диктанти фраз, що складаються з 2-3-4 слів, з опорою на сюжетну картинку, а пізніше без сюжетної картинки. Для відновлення зорових уявлень можна провести кілька вправ, що передбачають аналіз близьких до малюнку, за формою предметів, що відрізняються однією-двома ознаками (наприклад, чашки, чайника, цукорниці; шафи, холодильника, буфета; дивана, ліжка, кушетки; півня і курки; білки, лисиці, кішки і зайця тощо), у яких зміна або відсутність однієї з деталей міняє функцію предмета, його зміст і позначення. Крім того, учням дають завдання конструювати предмети з елементів, знаходити спеціально зроблені помилки в їх зображенні (наприклад, півень зображується з гребінцем, але без хвоста, заєць зображується без довгих вух, а кіт з довгими вухами тощо). Домалювати частину предмета, якої не вистачає, детально словесно описати всі його властивості і функції, впізнати предмет, наполовину прихований, за його частиною тощо. Усі перераховані вище прийоми подолання порушень слухомовленнєвої пам'яті, сприяють подоланню труднощів афазіі.

Труднощі знаходження потрібного слова долають шляхом розширення, а іноді і звуження смислових полів слова, тобто, шляхом уточнення і систематизації їх значень. Для цього конкретне слово обігрується в різних фразеологічних контекстах, звертається увага на багатозначність слова (ручка, ключ, мамина). Велика увага приділяється роботі з уточнення значення синонімів, антонімів і омонімів, складанню різних варіантів речень 3 цими словами.

Відновлення письмового висловлення є однією з основних форм розширення лексичного складу мови. Необхідно з перших днів корекційно-педагогічної роботи залучити учнів до складання письмових текстів, активної роботи 3 розширення словникового запасу, з подолання аграматизму. Роботу над складанням письмових текстів краще починати з написання фраз до простих сюжетних картинок, а потім використовувати різні карикатури в журналах, газетах. Це дасть змогу учневі будувати конкретні, невеликі за обсягом фрази і невеликі тексти. Потім можна запропонувати скласти письмові тексти за репродукціями відомих картин різних художників. Уся робота над письмовим текстом поєднується з усним мовленням. Учитель добирає легкі тексти, близькі до репродукцій, і просить учня переказати ї.

Аграматизм узгодження в роді і числі головних членів речення долається шляхом заміни іменників займенниками і займенників іменниками, а також шляхом складання фраз за опорним словами.

Приклад 4. Ольга Т. Сенсоневральна туговухість III ступеня. Дефіцитарний психічний розвиток у дитини з порушеннями слуху. Особливості пізнавальних процесів відповідають рівню затримки психічного розвитку. Емоційно-вольова сфера незріла. Обмежений рівень мовленнєвого розвитку. Має порушення поведінки.

Оля навчається в класі для дітей із порушеннями слуху за відповідною програмою. Дівчинка дуже любить привертати до себе увагу будь-яким способом (може вдарити, вкусити, подряпати однокласника). Мама учениці не виконує 


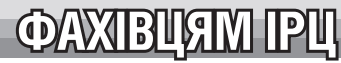

рекомендації психолога центру, що значно вповільнює досягнення поставлених нами завдань. Окрім корекційно спрямованого навчання для дітей з порушеннями слуху потребує певних методів та прийомів для корекції поведінки, а саме:

- для поліпшення навчальної роботи дитини ми вводимо знайому систему засобів - графіки, списки, годинники з дзвоником;

- робимо на уроці хвилинки активного відпочинку з легкими фізичними вправами й релаксацією.

- забезпечуємо дитину можливістю швидкого звернення за допомогою в випадках утруднення. Оля сидить у центрі класу, навпроти дошки, перед очима вчителя;

- виконуючи завдання діти часто не розуміють, що і як вони роблять, тому вчитель намагається вчасно допомогти і правильно організувати роботу дівчинки, щоб діяльність дитини на уроці не стала хаотичною;

- спрямовуємо зайву енергію учениці на виконання корисних завдань - під час уроку попросити допомоги, дати доручення вимити дошку, зібрати зошити тощо;

- робота з дівчинкою будується індивідуально, що прописуємо як у календарному плануванні, так і в конспекті уроку. Ми надаємо завдання в співвідношенні з робочим темпом і здібностями учня;

- на один відрізок часу - одне завдання. Якщо - одне завдання велике, пропонуємо у вигляді послідовних частин;

- забезпечуємо дитину умовами, у яких вона буде білыш зібрана;

- дотримуємося позитивної моделі поведінки. Не соромимося хвалити дитину. За відмінну поведінку та успіхи у навчанні нагороджуємо [11].

Приклад 5. Катерина С. Медичний висновок: двостороння сенсоневральна туговухість II ступеня. Синдром дефіциту уваги. Дефіцитарний психічний розвиток. Емоційно-вольова сфера незріла. Працездатність задовільна. Обмежений рівень мовленнєвого розвитку.

Вибір методів корекції СДУГ повинен мати індивідуальний характер з урахуванням ступеня вираженості основних проявів СДУГ і наявності супутніх йому порушень. При цьому корекція проявів СДУГ, як і діагностика цього синдрому, завжди повинні мати комплексний характер і об'єднувати різні підходи, зокрема роботу з батьками і методи модифікації поведінки (тобто спеціальні виховні прийоми), роботу зі шкільними педагогами, методи психолого-педагогічної корекції, психотерапії, а також медикаментозне лікування. Корекційна робота 3 гіперактивною дитиною повинна спрямовуватися на вирішення таких завдань:

- провести комплексну діагностику дитини, який виявляє симптоми дефіциту уваги та гіперактивності;

- нормалізувати обстановку в сім'ї дитини, його взаємовідносин з батьками та іншими дорослими. Важливо навчити членів сім'ї уникати нових конфліктних ситуацій;

- домогтися підвищення у дитини самооцінки, впевненості у власних силах за рахунок засвоєння ним нових навичок, досягнень успіхів у навчанні та повсякденному житті. Необхідно визначити сильні сторони особистості дитини і добре

«ОСОБЛИВА ДИТИНА: навчання і виховання», № 3, 2019 
розвинені у нього вищі психічні функції й навички з тим, щоб спиратися на них у подоланні наявних труднощів;

- досягти у дитини слухняності, прищепити ій акуратність, навички самоорганізації, здатність планувати і доводити до кінця початі справи. Розвинути у неї почуття відповідальності за власні вчинки;

- навчити дитину повазі до прав оточуючих людей, правильного мовного спілкування, контролю власних емоцій і вчинків, навичкам ефективного соціального взаємодії з оточуючими.

Організація корекційно-педагогічного процесу з гіперактивними дітьми повинна відповідати двом обов'язковим умовам:

- розвиток і тренування слабких функцій треба проводити в емоційно привабливій формі, що істотно підвищує сприймання запропонованого навантаження і мотивує зусилля з самоконтролю. Цій вимозі відповідає ігрова форма занять;

- підбір таких ігор, які, забезпечуючи тренування однієї функціональної здатності, не створювали б одночасного навантаження на інші дефіцитарні здібності, бо відомо, що паралельне дотримання двох, а тим більше трьох умов діяльності викликає у дитини істотні ускладнення, а часом просто неможливо виконати.

Навіть маючи бажання гіперактивна дитина не може виконати правила поведінки на уроці. Звідси основна умова розвитку дефіцітарних функцій у цих дітей - пропонуючи дитині гру, що вимагає напруги, зосередження, стриманості та довільного розподілу уваги, доцільно до мінімуму знизити навантаження на самоконтроль імпульсивності і не обмежувати рухову активність. Розвиваючи посидючість, не варто одночасно напружувати активну увагу і пригнічувати імпульсивність. Контроль за власною імпульсивністю не повинен супроводжуватися обмеженням можливості отримувати «м'язову радість» і може допускати певну частку неуважності. Проведена нами психокорекційна та корекційнопедагогічна робота представляе собою комплекс розвиваючих ігор, що дають можливість ізольовано впливати на окремі складові синдрому гіперактивності (Шевченко Ю. С., 1997; Шевченко Ю. С., Шевченко М. Ю., 1997). Так, нами було виділено кілька груп розвиваючих ігор для дітей з синдром гіперактивності, які можуть чергуватися в структурі єдиного ігрового сюжету спеціально організованих занять, а також вводитися у зміст вільного часу в школі і вдома:

1. Ігри на розвиток уваги, диференційовані за задіяними орієнтовними аналізаторами (зоровим, слуховим, вестибулярним, шкірним, нюховим, смаковим, тактильним) та за окремими компонентами уваги (фіксації, концентрації, утримання, переключення, розподіл); (стійкості, переключення, розподілу, обсягу).

2. Ігри на подолання ступору і тренування посидючості (що не вимагають напруги активної уваги і допускають прояви імпульсивності).

3. Ігри на тренування витримки і контроль імпульсивності (що дозволяють при цьому бути неуважним і рухомим).

4. Три види ігор із двоєдиним завданням (потребують бути одночасно уважним і стриманим, уважним і нерухомим, нерухомим і неімпульсивним);

5. Ігри з триєдиним завданням (з одночасним навантаженням на увагу, посидючість, стриманість). 
Тобто, фактично, кожній дитині пропонувався свій набір ігор, найбільш адекватний його порушенням. Ігри складені так, що при невиконанні ігрового завдання дитиною, його можна полегшити, змінити, зробити більш доступним для виконання на цьому етапі. Те саме відбувається при хорошому виконанні гри дитиною: гру можна ускладнювати, додавати нові правила, умови гри. Так, з одного боку - гра стає для дітей знайома й зрозуміла, а з іншого - не набридає з часом. Ігри виконуються спочатку індивідуально з кожною дитиною, пізніше краще використовувати групові ігрові завдання, в яких діти не тільки продовжують розвивати всі порушені компоненти уваги, долати імпульсивність і стримувати рухову розгальмування, а й вчаться взаємодіяти з іншими людьми, враховувати іх особистісні особливості. Ці ігри може проводити як на спеціальних заняттях психолог, так і вчитель на уроці під час так званої «фізкультхвилинки», а також батьки гіперактивної дитини вдома [11, 14].

Так, ми підійшли до того, що провідним видом діяльності молодшого школяра залишається гра, яка при правильному їі використанні містить великий корекційний потенціал.

Діти можуть відмовлятися виконувати завдання, а гратися - хочуть завжди! Наприклад, якщо учень із порушеннями слуху та інтелекту негативно реагує на нове завдання, ми можемо на випередження запропонувати йому руханку, дидактичну гру, що відволіче його від агресії, попередить виснаження, підготує до сприймання нового матеріалу.

У грі дитина уявляє себе дорослою, випробовує свої сили і самостійно розпоряджається всім тим, що створила вона сама. Саме тому гра є могутнім засобом виховання дітей із комплексними порушеннями. Під час гри учень набагато краще засвоює правила і необхідність іх виконання,у ній виховується витримка, воля, вміння володіти собою. Гра навчає єдиній колективній дії, виховує у дітей певну організованість. Під час гри дитина навчається долати труднощі, пізнає навколишній світ, шукає вихід із проблемної ситуації. Коли дитина отримує в грі певне завдання, вона виконує його не лише жестом, рухом, а й словами, намагаючись, щоб 㣙 мовлення було чітким, виразним, емоційно забарвленим Учні з порушеннями слуху починають вживати слова, які до цього часу були в пасивному словнику. Одночасно діти засвоюють нові слова, назви речей та їх властивостей значно швидше і міцніше, ніж поза грою. Дослідження О. Леонтьєва [12] довели, що кількість слів, які дитина може запам'ятати в грі, у два рази більша, ніж коли вона це робить за ініціативою дорослих. У грі розвиваються психічні процеси, удосконалюється мовлення, формуються моральні якості особистості. Отже, гра є провідною діяльністю молодшого школяра, у процесі якої відбуваються зміни у їі психічній та соціальній сфері, здійснюється підготовка до переходу на новий щабель розвитку. У спеціальних навчальних закладах існує своя специфіка організації та проведення ігрової діяльності, пов’язана з психофізичними та мовленнєвими особливостями дітей (І. Кривда, О. Рібцун, Ю. Рібцун та ін.) [14].

Для корекційної спрямованості навчання дітей з особливими освітніми потребами ми використовуємо такі ігри:

«ОСОБЛИВА ДИТИНА: навчання і виховання», № 3, 2019 
- на розвиток слухового сприймання («Спіймай звук», «Хто покликав?», «Де звук» тощо);

- сюжетно-рольові;

- мовні;

- для розвитку артикуляційного апарату;

- з розігруванням діалогів;

- з елементами лялькових театрів;

- пальчикові ігри для розвитку дрібної моторики, легоконструювання;

- ігри-драматизації та інсценування;

- народні ігри («Зустріч птахів», «Андріївські вечорниці» тощо).

Також у нашій практиці роботи з дітьми, що мають комплексні порушуення широко використовуємо корекцію методами арт-терапії :

- пісок, манка, малювання різними видами олівців, фарб, крейди;

- ліплення, конструювання, аплікація.

Фрми образного пізнання дійсності, стимулюють роботу обох півкуль головного мозку, розвивають дрібну моторику, фантазію, допомагають зблизити як педагога з дітьми, так і ровесників між собою, створюють позитивний емоційний настрій для засвоєння змісту навчального матеріалу, виховують естетичні смаки i, звичайно, стимулюють розвиток мовлення.

Висновок. Проаналізовано роботу вчителя $К 3 О$ «Багатопрофільний навчально-реабілітаційний ресурсно-методичний центр корекційної роботи та інклюзивного навчання» ДОР», починаючи зі знайомства з дитиною, вивчення діагнозу та анамнезу учня, розроблення індивідуальної програми розвитку, заведення щоденника педагогічних спостережень та індивідуальної карти супроводу, зошита взаємозв'язку з батьками. Також нами запропоновано деякі прийоми з реалізації індивідуального підходу до корекції, навчання та виховання учня з комплексними порушеннями в умовах багатопрофільного навчально-реабілітаційного центру.

\section{ЛITEPATУPA}

1. Альтернативні методи комунікації.- [Електронний ресурс] - Режим доступу до ресурcy: https://www.medel.com/support/rehabilitation/rehabilitation-downloads.

2. Антибура Ю. О. Індивідуальне навчання дітей зі складними порушеннями психофізичного розвитку як психолого-педагогічна проблема / Ю. О. Антибура // Вісник Дніпропетровського університету ім. Альфреда Нобеля. - Серія «Педагогіка і психологія». Педагогічні науки, № 2 (10). - 2015. [Електронний ресурс] - Режим доступу до ресурсу: http://pedpsy. duan.edu.ua/images/stories/Files/2015-2/11.pdf.

3. Базовий компонент дошкільної освіти [Богуш А. М., Бєлєнька Г. В., Богініч О. Л. та ін.]; наук. керівник: А. М. Богуш, дійсний член НАПН України, проф., д. п. н. - К. : ТОВ «МЦФЕР Україна», 2012. - 26 с.

4. Бондар B. інтеграція навчання дітей-інвалідів і дітей з обмеженими фізичними та розумовими можливостями: за і проти //Діти з обмеженими фізичними та розумовими можливостями в системі корекційного навчання і виховання: Матер. Міжнар. наук.-практ. конф. 27-28 травня 1997 р. / Ред. кол.: В. І. Бондар та ін.- К., 1997.- С. 7-9. 


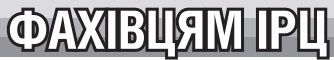

5. В Україні зростає кількість дітей з особливими потребами. - [Електронний ресурс] Режим доступу до ресурсу: https://www.obozrevatel.com/ukr/health/mamaclub/v-ukrainizrostae-kilkist-ditej-z-osoblivimi-potrebami.htm.

6. Діти зі складною структурою дефекту [Електронний ресурс] - Режим доступу до pecypcy: https://stud.com.ua/46688/pedagogika/diti_skladnoyu_strukturoyu_defektu.

7. Єжова Т.Є. Альтернативна комунікація як засіб соціальної реабілітації дітей з обмеженими можливостями життедіяльності [ Електронний ресурс] - Режим доступу до ресурсу: http://ap.uu.edu.ua/article/102.

8. Жигорева М. В. Дети с комплексными нарушениями в развитии: педагогическая помощь. - М.: Академия, 2006. - 240 с.

9.Засенко В., Колупаєва A. Шляхи інтеграції дітей з порушеннями слуху у суспільство // Громадянська освіта та соціалізація дітей з вадами слуху: 36. наук.-метод. матер.- К., 2002.C. $48-50$.

10. Інноваційні аспекти педагогічно-діагностичної діяльності закладів освіти по реабілітації дітей з вадами у розвитку [Текст] : метод. посіб. / Голов. упр. освіти і науки Дніпропетр. обл. держ. адмін., Дніпропетр. обл. ін-т післядиплом. пед. освіти, КЗО «Багатопроф. навч.-реабілітац. центр» Дніпропетр. обл. ради. - Д. : [б. и.], 2009 . Вип. 1 / упоряд. І. М. Родименко. - 2009. - 74 с.

11. Колупаєва А. А.,. Діти з особливими потребами в загальноосвітньому просторі: початкова ланка. / Колупаєва А. А.,, Таранченко О. М./ - К.: «АТОПОЛ», 2010.

12. Леонтьев А. Н. Язык, речь, речевая деятельность [текст] / А. Н. Леонтьев. - М. : Просвещение, 2007. - 289 с.

13. Обухівська А. Г. Методичні та організаційні питання діагностико-консультативної діяльності психолого-медико-педагогічних консультацій / А. Г. Обухівська, Т. Д. Ілляшенко, Т. В. Жук та ін. - Київ : УНМЦ практичної психології і соціальної роботи, 2017. - 78 с.

14. Рібиун Ю. В. Дошкільнятко: корекційно-розвивальна та навчально-виховна робота 3 дітьми з фонетико-фонематичним недорозвитком мовлення : навч.-метод. посіб. / Ю. В. Рібцун. - К., 2014. -238 с.

15. Родименко I. М. Іноваційні технології інклюзії в навчально-виховному процесі у багатопрофільному навчально-реабілітаційному ресурсно-методичному центрі корекційної роботи та інклюзивного навчання / I. М. Родименко // Освіта осіб з особливими потребами: шляхи розбудови. - 2014. - Вип. 7. - С. 98-102. - Режим доступу: http://nbuv.gov.ua/UJRN/ ooop_2014_7_16.

16. Статистичні дані/ Міністерство освіти і науки України. [Електронний ресурс]. Режим доступу: https://mon.gov.ua/ua/statistichni-dani.

17. Хохліна О. П. Корекційно-розвивальна робота в спеціальних закладах освіти для дітей 3 порушеннями психофізичного розвитку: теоретичний аспект проблеми [Електронний ресурс] / О. П. Хохліна - Режим доступу до ресурсу: http://ap.uu.edu.ua/article/416.

\section{REFERENCES (TRANSLATED AND TRANSLITERATED)}

1. Alternatyvni metody komunikatsii [Elektronnyi resurs] - Rezhym dostupu do resursu: ttps://www.medel.com/support/rehabilitation/rehabilitation-downloads.

2. Antybura Yu.O., 2015. Indyvidualne navchannia ditei zi skladnymy porushenniamy psykhofizychnoho rozvytku yak psykholoho-pedahohichna problema [Elektronnyi resurs] / Yu.O. Antybura // VISNYK DNIPROPETROVSKOHO UNIVERSYTETU IMENI ALFREDA NOBELIa. 
Seriia «PEDAHOHIKA I PSYKhOLOHIIa». Pedahohichni nauky, № 2 (10). -- Rezhym dostupu do resursu: http://pedpsy.duan.edu.ua/images/stories/Files/2015-2/11.pdf.

3. Bazovyi komponent doshkilnoi osvity [Bohush A. M., Bielienka H. V., Bohinich O. L. ta in.]; nauk. kerivnyk: A. M. Bohush, diisnyi chlen NAPN Ukrainy, prof., d. p. n. - K. : TOV «MTsFER Ukraina», 2012. - $26 \mathrm{~s}$.

4. Bondar V. 1997.- intehratsiia navchannia ditei-invalidiv i ditei z obmezhenymy fizychnymy ta rozumovymy mozhlyvostiamy: za i proty //Dity z obmezhenymy fizychnymy ta rozumovymy mozhlyvostiamy v systemi korektsiinoho navchannia i vykhovannia: Mater. Mizhnar. nauk.-prakt. konf. 27-28 travnia 1997 r. / Red. kol.: V,I. Bondar ta in.- K., S. 7-9.

5. V Ukraini zrostaie kilkist ditei z osoblyvymy potrebamy. - [Elektronnyi resurs] - Rezhym dostupu do resursu: https://www.obozrevatel.com/ukr/health/mamaclub/v-ukraini-zrostaekilkist-ditej-z-osoblivimi-potrebami.htm.

6. Dity zi skladnoiu strukturoiu defektu [Elektronnyi resurs] - Rezhym dostupu do resursu: https://stud.com.ua/46688/pedagogika/diti_skladnoyu_

strukturoyu_defektu.

7. Yezhova T. Ye. Alternatyvna komunikatsiia yak zasib sotsialnoi reabilitatsii ditei z obmezhenymy mozhlyvostiamy zhyttiediialnosti [ Elektronnyi resurs] - Rezhym dostupu do resursu: http:// ap.uu.edu.ua/article/102.

8. Zhyhoreva, M. V., 2002.- Dety s kompleksnumy narushenyiamy v razvytyy: pedahohycheskaia pomoshch. - M.: Akademyia, 2006. $-240 \mathrm{~s}$.

9. Zasenko V., Kolupaieva A., 2002.- Shliakhy intehratsii ditei z porushenniamy slukhu u suspilstvo // Hromadianska osvita ta sotsializatsiia ditei z vadamy slukhu: 36 . nauk.-metod. mater.- K., S. 48-50.

10. Innovatsiini aspekty pedahohichno-diahnostychnoi diialnosti zakladiv osvity po reabilitatsii ditei z vadamy u rozvytku [Tekst] : metod. posib. / Holov. upr. osvity i nauky Dnipropetr. obl. derzh. admin., Dnipropetr. obl. in-t pisliadyplom. ped. osvity, KZO "Bahatoprof. navch.-reabilitats. tsentr" Dnipropetr. obl. rady". - D. : [b. y.], 2009 . Vyp. 1 / uporiad. I. M. Rodymenko. - 2009. - 74 s.

11. Kolupaieva A. A., 2010. Dity z osoblyvymy potrebamy v zahalnoosvitnomu prostori: pochatkova lanka. / Kolupaieva A. A.,, Taranchenko O. M.../ - K.: "ATOPOL".

12. Leontev A. N., 2007. Yazik, rech, rechevaia deiatelnost [tekst] / A. N. Leontev. - M. : Prosveshchenye, $-289 \mathrm{~s}$.

13. Obukhivska A. H. Metodychni ta orhanizatsiini pytannia diahnostyko-konsultatyvnoi diialnosti psykholoho-medyko-pedahohichnykh konsultatsii / A. H. Obukhivska, T. D. Illiashenko, T. V. Zhuk ta in. - Kyiv : UNMTs praktychnoi psykholohii i sotsialnoi roboty,- $78 \mathrm{~s}$.

14. Ribtsun Yu. V., 2017. Doshkilniatko: korektsiino-rozvyvalna ta navchalno-vykhovna robota z ditmy z fonetyko-fonematychnym nedorozvytkom movlennia : navch.-metod. posib. / Yu. V. Ribtsun. - K., 2014. - 238 s.

15. Rodymenko I. M., 2014. Inovatsiini tekhnolohii inkliuzii v navchalno-vykhovnomu protsesi u bahatoprofilnomu navchalno-reabilitatsiinomu resursno-metodychnomu tsentri korektsiinoi roboty ta inkliuzyvnoho navchannia / I. M. Rodymenko // Osvita osib z osoblyvymy potrebamy: shliakhy rozbudovy. - Vyp. 7. - S. 98-102. - Rezhym dostupu: http://nbuv.gov.ua/UJRN/ooop_2014_7_16.

16. Statystychni dani/ Ministerstvo osvity i nauky Ukrainy. [Elektronnyi resurs]. - Rezhym dostupu: https://mon.gov.ua/ua/statistichni-dani

17. Khokhlina O. P. Korektsiino-rozvyvalna robota v spetsialnykh zakladakh osvity dlia ditei z porushenniamy psykhofizychnoho rozvytku: teoretychnyi aspekt problemy [Elektronnyi resurs] / O. P. Khokhlina - Rezhym dostupu do resursu: http://ap.uu.edu.ua/article/416. 